\title{
THE IMPACT OF INFRASTRUCTURE DEVELOPMENT FOR A CIRCULAR ECONOMY: THE CASE OF SUSTAINABLE DEVELOPMENT OF IRAQ
}

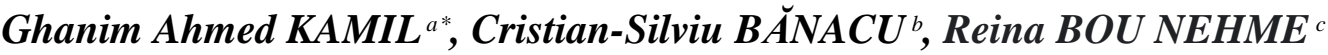 \\ ${ }^{a, b, c}$ Bucharest University of Economic Studies Romania
}

DOI: $10.24818 / \mathrm{IMC} / 2020 / 03.13$

\begin{abstract}
:
The infrastructure is one of the great important sectors in countries as it has become a measure of the extent of development of these countries and its effects on the state in general and the economy in particular, and the issue of economic growth and creating opportunities, because of its clear reflection on economic stability. Economic development without tangible progress in the initial quality and presence of infrastructure.

Therefore, the aim of this paper is to classify the concepts of both infrastructure and economy, and we will see how they have a direct impact on the country, the approach of this paper will start from the most important part or the largest part of the infrastructure which support the country and create part of the economy or the vision for the future of Iraq, and in the end the results of this The paper provides some analysis and diagramming strategies for these elements which will support our objectives in the paper.
\end{abstract}

KEYWORD: infrastructure, economy, development, transport investment.

\section{INTRODUCTION}

The importance of infrastructure is great for the country and this can be seen through the direct impact that it leaves on the country in general and the economy in particular, specifically the issue of economic growth and the generation of opportunities, due to its clear reflection on economic stability. Economic growth and the generation of opportunities are reflected in economic stability, without tangible progress in the quality of the infrastructure as well as its presence in the beginning.

The World Bank released its report titled "The Lifeline: The Opportunity for Resilient Infrastructure" on June 19, 2019, to signify its importance, and considers it "the essence of life and the pillar of livelihoods, and it can improve the work of schools, hospitals, business and industry, as well as opportunities to find jobs and achieve prosperity." As the president of the World Bank Group says. The main problem of this paper to explain and prove that how is the infrastructure in Iraq has direct impacting on the economy and we want to make this point more clear to the Iraqi government instead of their depending on the oil industry only , may researcher did about the infrastructure and the economy and the relations between them and they reached that there are many points have impact on each other , my contribution in this paper to make this problem more clear by considering some analysis and classifying the elements of this paper one by one which I did already and I reached to main goal of thus paper and I proved that the infrastructure is very important and it has impact on the economy of Iraq .

\footnotetext{
*Corresponding author, email: aghanim295@gmail.com
} 


\section{INFRASRUCTURE OF IRAQ}

At a time when Iraq suffers from the significant damage to infrastructure, which is reflected in the high deprivation of families from their services, as their deprivation rate reached $58.95 \%$ in 2010 , and this percentage is very high by international standards(1). The Iraq's economy suffers from the dichotomy of oil and the state, which has negatively affected infrastructure and finally economic stability, as the economy's dependence on oil and neglecting other sectors means generating more unemployment, which has taken on frightening numbers from $10 \%$ to $40 \%$, especially since its industry is an industry. It is capital intensive and not labor intensive, as $1 \%$ of Iraqis work in the oil sector in exchange for its revenues, which constitute $99 \%$ of government revenues (2). It is necessary to refer to the remarkable change in the infrastructure of Iraq, such as the change in the electricity sector, transportation, bridges, railways, and airports, but the Iraqi government still has a lot of work and investment in these sectors in line with the rapid growth of the population (3). After the war of 2003 The Iraqi government decided that the first Coalition Provisional Authority (CPA) reconstruction plan had four 'pillars': justice, security, governance, and infrastructure. For infrastructure it involved big money being poured into hundreds (and eventually thousands) of projects. The concept was that, with a repaired infrastructure, the economy would recover and grow naturally (4), from her the Iraqi government it's start to recognize that the infrastructure is one of the good source to the economy beside the oil for few years only because the corruption and the war after 2003 make the government and the country focus only on the oil industry but they took in consider that the developing in the infrastructure of Kurdistan religion ( north of Iraq ) is became one of the main source of their economy and they did the plan for many projects to rebuild and develop the infrastructure but the non-secure case make the projects and the investors to not start now.

\section{THE INFRUSTRUCTURE LEAD TO ECOMOMIC STABILITY}

The infrastructure in developing countries or countries that are subjected to many wars or exceptional circumstances that would tempt the permanence of this infrastructure or limit its maintenance or even its development will be in the focus of attention of investing countries or even international companies interested in investing in such sectors. Therefore, these investments play a big role in that country, where when the infrastructure is integrated and of high quality and reasonable prices, this will be reflected in many things, down to the prices of goods, services and job opportunities in that country, and this in turn drives the economic wheel in that country and achieves the economic stability of the country and same case as a negative result if the country was facing problems as wars or deferent things which make the investors don't have the desire to come and start their investing . Infrastructure is beneficial for both businesses and households and for the economy broadly. For businesses, infrastructure can help to lower fixed costs of production, especially transportation costs, which are often a central determinant of where businesses are located (5).

\section{INVESTMENT PRIJECTS OF INFRUSTRUCTURE}

After the last war in 2014 which was for three years the government recognize and decided that must put a plan and make other resources for the income, there are many investment and project some of them thy are start to do on the reality and the rest of them only on paper:

\subsection{Health sector's status and development:}

Health indicators is of great importance to growth, standard of living and human capacity building. It is well known that the health status of the people in any country is considered as a main factor in the economic growth of the country. In Iraq, the Ministry of Health is in charge of determining the health level within a large system of hospitals and different medical clinics in addition to the private health 
sector represented by private hospitals and private medical clinics, Number of hospitals in Iraq (public and private) till 2018 is 380 hospitals and 1620 healthcare center (except KRG)(6)

Table 1. Investment opportunities in health sector announced by the $\mathrm{MoH}$

\begin{tabular}{|c|l|l|l|}
\hline No. & Project name & $\begin{array}{l}\text { Achievement } \\
\text { rate }\end{array}$ & Province \\
\hline $\mathbf{1}$ & $400-$ bed hospital & $\% 30$ & Wasit \\
\hline $\mathbf{2}$ & $200-$ bed hospital & $\% 56$ & $\begin{array}{l}\text { Anbar/ } \\
\text { Haditha }\end{array}$ \\
\hline $\mathbf{3}$ & $300-$ bed hospital & $\% 29$ & Karbala \\
\hline $\mathbf{4}$ & $200-$ bed hospital & $\% 17$ & $\begin{array}{l}\text { Baghdad/ Al } \\
\text { Husaynia }\end{array}$ \\
\hline $\mathbf{5}$ & $400-$ bed hospital & $\% 25$ & Kirkuk \\
\hline $\mathbf{6}$ & $400-$ bed hospital & $\% 26$ & Al Muthana \\
\hline $\mathbf{7}$ & $100-$ bed hospital & $\% 37$ & $\begin{array}{l}\text { Saladin/ } \\
\text { Samara }\end{array}$ \\
\hline $\mathbf{8}$ & $100-$ bed hospital & $\mathbf{\% 3 0}$ & Saladin/ Dejail \\
\hline $\mathbf{1 0 0}-$ bed hospital & Saladin/ Tooz \\
\hline
\end{tabular}

Moh letter no. 73629 in 16/2/2018

Source: National Investment Commission (2019) 


\begin{tabular}{|c|c|c|c|}
\hline No & Project's Name & $\begin{array}{l}\text { Type of Investment } \\
\text { Opportunities }\end{array}$ & Province \\
\hline 1. & Specialized cancer treatment center & New & $\begin{array}{l}\text { Baghdad, Al Karkh and } \\
\text { Al- Rusafa }\end{array}$ \\
\hline 2. & $\begin{array}{l}\text { Arabic Child Hospital in Al-Karkh } \\
\text { ( } 50 \text { beds) }\end{array}$ & New & Baghdad/ Al-Karkh \\
\hline 3. & $\begin{array}{l}\text { 3-4 Drugs and medical } \\
\text { appliances factory. }\end{array}$ & New & $\begin{array}{l}\text { Baghdad, Al Karkh } \\
\text { and Al- Rusafa }\end{array}$ \\
\hline 4. & 2 Sterility and fertility hospital & New & $\begin{array}{l}\text { Baghdad in Al Karkh } \\
\text { and Al- Rusafa }\end{array}$ \\
\hline 5. & 2 Specialized ophthalmology hospital & New & $\begin{array}{l}\text { Baghdad, Al Karkh } \\
\text { and Al- Rusafa }\end{array}$ \\
\hline 6. & 1 Specialized cardiac surgery hospital & New & $\begin{array}{l}\text { Baghdad, Al Karkh } \\
\text { and Al- Rusafa }\end{array}$ \\
\hline 7. & 2-3 hydrogen peroxide (pure O2) Plant & New & $\begin{array}{l}\text { Baghdad, Al Karkh } \\
\text { and Al- Rusafa }\end{array}$ \\
\hline 8. & 2 Complete medical city & New & Baghdad, Al Karkh \\
\hline 9. & $\begin{array}{l}4 \text { General hospitals, capacity: } 50 \\
\text { bed each }\end{array}$ & New & $\begin{array}{l}\text { Baghdad, Al-Karkh } \\
\text { and Al- Rusafa }\end{array}$ \\
\hline 10. & $\begin{array}{l}4 \text { Specialized medical centers, } \\
\text { capacity: ( } 20 \text { bed or more) }\end{array}$ & New & $\begin{array}{l}\text { Baghdad, Al-Karkh } \\
\text { and Al- Rusafa }\end{array}$ \\
\hline 11. & $\begin{array}{l}\text { Joint venture with international } \\
\text { companies' hospital management } \\
\text { and other medical fields }\end{array}$ & $\begin{array}{l}\text { Contracting with } \\
\text { specialized companies to } \\
\text { open new hospitals in Iraq }\end{array}$ & $\begin{array}{l}\text { Baghdad, Al-Karkh } \\
\text { and Al- Rusafa }\end{array}$ \\
\hline 12. & $\begin{array}{l}\text { Extra governmental hospitals to be } \\
\text { submitted as an investment } \\
\text { opportunity }\end{array}$ & $\begin{array}{l}\text { Contracting with } \\
\text { specialized companies to } \\
\text { open new hospitals in Iraq }\end{array}$ & $\begin{array}{l}\text { Baghdad, Al-Karkh } \\
\text { and Al- Rusafa }\end{array}$ \\
\hline 13. & $\begin{array}{l}1 \text { General hospital capacity: (100 } \\
\text { beds) area } 2 \text { dumun }\end{array}$ & New & Wasit/ Kut city center \\
\hline 14. & $\begin{array}{l}1 \text { Specialized Heart and Blood } \\
\text { Vessels Surgery }\end{array}$ & New & Wasit/ kut \\
\hline 15. & 1 Specialized gynecology Center & New & Wasit/ kut \\
\hline 16. & $\begin{array}{l}1 \text { Specialized Infertility and IVP } \\
\text { (Tube Baby) Center }\end{array}$ & New & Wasit/ kut \\
\hline 17. & $\begin{array}{l}\text { 1Specialized ophthalmology } \\
\text { Surgery hospital ( } 50 \text { beds) }\end{array}$ & New & Wasit/ city center \\
\hline 18. & 1 Specialized oncology Center & New & Wasit/ city center \\
\hline 19. & General hospital 100 beds & new & Wasit/ Swaiyra \\
\hline 20. & $\begin{array}{l}1 \text { Specialized in Laparoscopic } \\
\text { surgery and laser center }\end{array}$ & New & Wasit/ Kut \\
\hline 21. & 1 Specialized Plastic Surgery Center & New & Wasit/ Kut \\
\hline 22. & 1 Complete Medical City & New & Wasit/ Kut \\
\hline 23. & Medical Supplies and drugs Plant & New & Wasit/ Swaiyra- Kut \\
\hline 24. & 1 General hospital 1000 dunum & New & Holy Najaf \\
\hline
\end{tabular}




\begin{tabular}{|c|c|c|c|}
\hline No & Project's Name & $\begin{array}{l}\text { Type of Investment } \\
\text { Opportunities }\end{array}$ & Province \\
\hline 25. & $\begin{array}{l}1 \text { General hospital plot 25/2738 m5 } \\
\text { Um Abasyat (10 dunum) Al Shafiya }\end{array}$ & New & Al-Diwaniah \\
\hline 26. & $\begin{array}{l}1 \text { General hospital plot } 18 / 4105 \text { m18 } \\
\text { Sadir Al Yousfiya (4 donum) Ifak }\end{array}$ & New & Al-Diwaniah \\
\hline 27. & $\begin{array}{l}1 \text { General hospital capacity: plot } \\
\text { 21/14 m2 Al Hebsa } 6 \text { dunum }\end{array}$ & New & Al-Diwaniah \\
\hline 28. & $\begin{array}{l}\text { Specialized Major Surgery Center } \\
\text { (cardiac \& blood vessels, } \\
\text { neurosurgery, oncology) }\end{array}$ & $\begin{array}{l}\text { New (estimated cost } \$ 5 \\
\text { million, } 4000 \mathrm{~m}^{2} \text { area in } \\
\text { the commercial zone in } \\
\text { Ramadi }\end{array}$ & Anbar \\
\hline 29. & $\begin{array}{l}\text { Medical equipment, Stethoscope } \\
\text { medical beds, gauze, medical cotton, } \\
\text { bandage, wheelchairs for people } \\
\text { with special needs and handicaps, all } \\
\text { kinds of tubes used for laboratory } \\
\text { samples, blood pressure monitor, all } \\
\text { types of needles, medical waste } \\
\text { containers , blood transfusion } \\
\text { equipment, temperature gauge, etc.) }\end{array}$ & New & Anbar \\
\hline
\end{tabular}

Table 2. Investment opportunities in health sector announced by the provinces Source: National Investment Commission (2019)

\subsection{Housing and infrastructure sector}

Economically speaking, housing is a very vital sector for the important roles it plays in the formation of the fixed capital, generating incomes and creating job opportunities and through the connection with other activities. Many countries which enjoy financial surpluses go to maximizing the role of this sector, in other words considering it as a producing sector.

The Government of Iraq granted the private sector and the foreign investor the enabled role that may achieve touchable results in the housing production field by providing the lands suitable for housing purposes which will contribute to treating the problem of the residential slums and expanding in manufacturing the construction materials, taking into consideration the average growth of the Iraqi population and the fact of the need of 2 million housing units (6).

Table 3: Investment opportunities in health sector announced by provinces.

\begin{tabular}{|l|c|}
\hline \multicolumn{1}{|c|}{ Province/ Region } & Number of units \\
\hline Anbar & 45 thousand units \\
\hline Babylon & 54 thousand units \\
\hline Baghdad & 224 thousand units \\
\hline Basra & 80 thousand units \\
\hline
\end{tabular}




\begin{tabular}{|l|c|}
\hline \multicolumn{1}{|c|}{ Province/ Region } & Number of units \\
\hline Diwania & 35 thousand units \\
\hline Diyala & 43 thousand units \\
\hline Holy Kerbala & 31 thousand units \\
\hline Kirkuk & 40 thousand units \\
\hline KRG & 140 thousand units \\
\hline Maysan & 31 thousand units \\
\hline Muthana & 22 thousand units \\
\hline Holy Najaf & 37 thousand units \\
\hline Nineveh & 101 thousand units \\
\hline Saladin & 39 thousand units \\
\hline Thi Qar & 58 thousand units \\
\hline Wassit & 36 thousand units \\
\hline
\end{tabular}

Source: National Investment Commission (2019)

\subsection{Transportation sector}

This sector is characterized by a big contribution of the local and foreign private sector and investments in implementing and operating lots of its projects. The contribution of this sector to the GDP in the fixed prices was approximately \%7.8 for the year 2018, Iraq has planned to exploit its special geographic location in developing the transport sector in all its branches (land, maritime and air), the matter that will help in achieving the economic growth and creating lots of job opportunities in the international commercial businesses especially when developing the sector's infrastructure which will result in diversifying revenues and providing better services to people and all users(6). As we can see in these tables the Iraqi government, they have the plan for all the sectors specially for the infrastructure sector because the state to see and notes that must be other sources for the income and should establish a strong based to make the economy with balance.

\section{CONCLUSIONS}

The Iraqi government recognized after many wars that must they establish other sources instead the oil sector. Beside that They notes that there are two things make the investment and the projects difficult to start and work with because the country is not secure for the investors for that the Kurdistan region is more develop than another place in Iraq. Moreover, they consider the infrastructure sector is one of the main sources for the economy in Iraq, In the end of the conclusions There is direct impact between the infrastructure and the economic stability in Iraq Depending on what was presented in the plans and project lists. 


\section{REFERENCES}

Annabaa. (2019). Rolul infrastructurii in stabilitatea economica. Retrieved from https://m.annabaa.org/arabic/economicarticles/20056

Barakat. S. (2005). Reconstructing Post-Saddam Iraq: an introduction. Third World Quarterly, (26)4, 565 -570 .

National Investment Commission. (2019). Investment Map of Iraq. Presidency of Council of Ministers, Republic of Iraq. https://investpromo.gov.iq/wp-content/uploads/2019/05/investmentMap-2019-En.pdf

OECD. (2010). Reinforcing Infrastructure Development in Iraq. Paper presented at the $2^{\text {nd }}$ Meeting of the Working Group on Infrastructure Finance in Iraq. Paris, France.

Romp, W. \& De Haan, J. (2007). Public Capital and Economic Growth: A Critical Survey. EIB Papers, 10(1), $41-70$.

UNDP Iraq. (2020). Sustainable Development Goals. Retrieved from https://www.iq.undp.org/content/iraq/en/home.html.html 